\title{
Competence Role of LPD Management in Moderating Organizational Culture Relationship to Organizational Performance
}

\author{
Dewa Ayu Rumini ${ }^{1}$, A A. Media Martadiani ${ }^{2}$ \\ \{dewaayurumini@gmail.com¹, mediamartadiani@gmail.com² \\ Faculty Ekonomi Universitas Warmadewa Denpasar-Bali, Indonesia ${ }^{12}$
}

\begin{abstract}
In conditions of increasing competition today, to realize organizational performance there are several factors that must be considered and known by academics and practitioners. Factors that influence organizational performance one of them is organizational culture. This study examines the Role of LPD Management Competence in Moderating the Relationship of Organizational Culture to Organizational Performance (Empirical Study on LPD in Tabanan Regency) so as to improve LPD performance. The study population was LPDs registered and still active throughout Tabanan Regency. The sampling method in this study used the stratified random sampling method with 150 samples. The statistical analysis tool used to test the hypothesis is a structural equation model (Structural Equation Modeling) commonly called SEM with the WarpPLS version 6.00 program. The results of this study found that organizational performance (LPD) is influenced by organizational culture factors, but when organizational culture interacts with management competencies it is not able to influence organizational performance. LPD. From these findings it can be concluded that management competency is not as a moderation of organizational cultural relations with the performance of LPD organizations.
\end{abstract}

Keywords: Organizational Culture, Management Competence, Organizational Performance.

\section{Introduction}

LPD is an institution established specifically for the sake of the welfare of the people of Pakraman village, in its activities only serving and protecting the community of Pakraman Village only. LPDs have an important role in serving Pakraman villagers including micro and household small businesses in Pakraman village, which are in line with the expectations of customers, namely simple procedures, fast processing, and proximity to their location.

In several studies in the field of management, organizational culture is a major factor in organizational life. The effect of this type of organizational culture on organizational performance is questionable. The increasingly complex effects of organizational determination on strategies that enable the achievement of organizational levels can play an important role in the relationship between organizational culture and organizational performance. The most important step to realize organizational performance is to increase the productivity of human resources, create consistent rules and working mechanisms and channel funds / operational costs that are truly used for the benefit of the organization directly in accordance with their interests and efficiency and effectiveness programs carried out evenly on all lines or sections in the scope of the organization, and efficiency must continue to be carried out under any conditions, provided that it does not hinder the performance of the organization.

[1] states that business performance in this case LPD should be measured by the Balanced Scorecard approach, in an effort to improve management capabilities. And it was stated that business development must be balanced with the evaluation and control of relevant government institutions in fostering small companies. In terms of business actors, in this case the LPD is closely related to the individual performance of the business manager itself. Managers who have strong competence and motivation as well as implementing a strong organizational culture (business ethics) make their company performance better.

Some studies related to the relationship of organizational culture to organizational performance are carried out by [2]. [2] examines the relationship of corporate culture and organizational commitment to financial performance in financial companies in Surabaya. The results of the study prove that applying organizational culture can improve the company's financial performance. In other words, organizational 
culture has a significant influence on the financial performance of financial companies in Surabaya. LPD financial performance is measured by ROA (Return On Asset). Building a strong organizational culture can be used as a guide to improve the performance of the organization concerned.

The results of the same research are also proven by [3] [4] [5], [6]). The results of the study obtained evidence that organizational culture has a positive and significant influence on company performance, meaning that organizational culture which is the result of the interaction of habit characteristics that affect groups of people in the organizational environment, will form an overall subjective perception of the organization based on factors factors such as risk tolerance, pressure on the team, and people's support, this overall perception will be the culture or personality of the organization that is able to support and influence employee job satisfaction and company performance as well as a greater impact on a stronger culture.

The relationship between Organizational Culture and Employee Performance was also found in research conducted by [7] stating that Organizational Culture has a positive influence on Employee Performance. The results of the study [8], [9] and [10] show a significant relationship between organizational culture and employee performance. showing the existence of a positive relationship between culture and performance helps in improving organizational outcomes. The work performance of the organization has a strong impact on a strong organizational culture because it increases the productivity of the company. The results of this study support several opinions and theories about organizational culture which state that the type of organizational culture is closely related to several dimensions of organizational performance. The relationship between organizational culture and organizational efficiency influences internal stability or variability and external environment. Organizational culture can be a strategic asset for the organization because it will improve adaptability and fit between the organization and its environment. But the results of different studies were found by [11]. The results of this study prove that organizational culture is negatively related to leadership. This finding is also supported by [12]. [12] prove that organizational culture has a negative and insignificant effect on employee performance in the North Sumatra UPTD Tondano Dispenda. The existence of organizational culture in each company has not been able to improve employee performance, leadership which ultimately has an impact on the organization.

There are still variations in research findings as a research gap, motivating this study. The inconsistency of the results of the study is thought to be influenced by management competence. In this study management competence is a moderating variable because organizational culture is an active and living phenomenon where the key to an organization is management competencies that shape and influence organizational culture, how to make decisions, management styles and behavioral models in organizations [13]. Leaders also play a central role in shaping and controlling organizational culture [14]. Although the founder had an initial role in building organizational culture, culture was known to change in the next hand, management [15]. Management also plays a central role in shaping and controlling organizational culture [14].

Empirically [16] proves that HR competence has a significant effect on employee performance. company. With high competency, the employee's performance also increases, the significance of which is on organizational performance. [17] also proves that management competence influences organizational performance. In order to develop SMEs, they should pay attention in terms of the competence of SME HR involved in running their businesses so that SMEs can exist and can compete better both nationally and globally. This finding is also supported by [18] and [19]. That employee performance is influenced by employee competence will later impact on organizational performance.

\section{Research Methods}

The type of data used is primary data. Primary data is obtained by using a questionnaire that contains the opinion of the LPD management about the indicator variables studied using the survey method. The population of this study is all LPDs registered in Tabanan Regency. By using the sampling method in this case using multi-stage sampling, namely by using stratified random sampling and random sampling obtained a sample of 150 LPDs.

Constructs are variables that still cannot be measured directly. Therefore, it is necessary to describe such constructs into measurable dimensions and elements. The construct elements that can be measured are used as the basis for preparing statements or questions in the questionnaire. The data analysis method used in this study is to use the WarpPLS 2.0 program. By using structural equation models SEM (Structural Equation Modeling) with mediating effects, that is a relationship between exogenous and 
endogenous constructs through connecting or intermediate variables. This means that the influence of exogenous variables on endogenous variables can be directly but also through supporting variables or mediation. Hypothesis testing uses the WarpPLS 6.0 program. The assumption of WarpPLS is that it does not require the assumption of normal data distribution, because it has been fulfilled with the resampling method [20] of the 150 questionnaires distributed, questionnaires were returned and could be processed at $150(100 \%)$.

\section{Data Analysis}

The next step is to do structural evaluation (Inner Model) which includes the model fit test (model fit) $\mathrm{R}^{2}$ coefficient path. To assess the results of a model it is said that the fit in the WarpPLS 6.0 program can be seen from the general results output. It can be seen from the fit indices and p-values showing 10 fit indicators, namely:

a. Average path coefficient (APC) has a value) $\mathrm{p}<0.05$

b. Average R-Squared (ARS) has a value of $\mathrm{p}<0.05$.

c. The Average Adjusted R-Squared (AARS) has a value of $p<0.05$

d. Average Block Variance Inflation (AVIF) has a value of $<5$ and ideally 3.3

e. Average full collinearity VIF (AFVIF) has a value of $<5$ and ideally 3.3

f. Tenenhaus GoF (GoF) has a value of small $>=0.1$, medium $>=0.25$, large $>=0.36$.

g. Sympson's Paradox Ratio (SPR) has a value of $>0.7$ and ideally 1

h. R-Squared Contribution Ratio (RSCR) has a value $>=0.9$ and ideally 1 .

i. Statistical Suppression Ratio (SSR) is accepted if the value is $>0.7$

j. Nonlinear Bivariate Causality Direction Ratio (NLBCDR) is accepted if the value $>=0.7$.

The following are the Fit and quality Indices model tables.

Table 1. Fit and Quality Indices Model

\begin{tabular}{rcccc}
\hline Model fit and quality indices & Indeks & p-value & Kriteria & Keterangan \\
\hline Average path coefficient (APC) & 0.085 & $\mathrm{P}=0.023$ & $\mathrm{P}<0,05$ & Accepted \\
Average R-Squared (ARS) & 0.213 & $\mathrm{P}=0.015$, & $\mathrm{P}<0,05$ & Accepted \\
Average Adjusted R-Squared & 0.245 & $\mathrm{P}=0.002$ & $\mathrm{P}<0,05$ & Accepted \\
Average Block Variance & 1,000 & $\leq 5$ dan & ideal $\leq 3,3$ & Accepted \\
Inflation Factor (AVIF) & & & & \\
Average Full Collonearity VIF & 1,007 & $\leq 5$ dan & ideal $\leq 3,3$ & Accepted \\
Tenenhaus GoF (GoF) & 0,0066 & & & Small \\
Sympson's paradox ratio (SPR) & 1,000 & $\geq 0,7$ dan & ideal $=1$ & Accepted \\
R-Squared Contribution Ratio & 1,000 & $\geq 0,9$ dan & ideal $=1$ & Accepted \\
(RSCR) & & & $\geq 0,9$ & Accepted \\
Statictical Suppression Ratio & 1,000 & & $\geq 0,7$ & Accepted \\
(SSR) & & & & \\
Nonlinear Bivariate Causality & 1,000 & & & \\
Direction Ratio (NLBCDR) & & & & \\
\end{tabular}

Primary Data Source Processed, 2018 
The model estimation results can be described as follows:

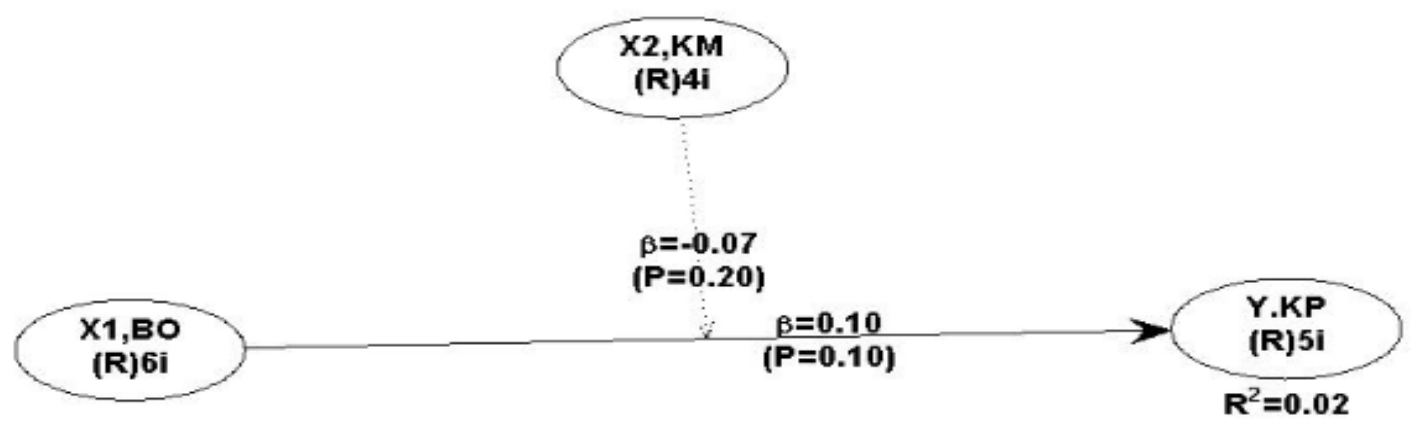

Fig. 1. Model Testing Results

The results of hypothesis testing using WarpPLS 6.0 can be generated as follows: H1: Organizational culture has a positive and significant effect on organizational performance. Obtained coefficient value of 0.10 and $p$ value $<0.10$ can be concluded significant at $\alpha=10 \%$ AND H2: Management competency has a positive and significant effect on organizational performance. Obtained a coefficient value of -0.07 and $p$ value $<0.20$ can be concluded negative effect and not significant at $\alpha=5 \%$ Supporting the hypothesis 1 (H1) this proves that the theory of organizational culture that with a strong organizational culture can increase company productivity and in the end the company's performance also increases. The results of this study support the results of previous studies from [7], [8], [9] and [10]

However, different results were obtained from testing the second hypothesis $(\mathrm{H} 2)$, namely management competency was not able to moderate the relationship of organizational culture with LPD performance. This can be justified that the LPD in Bali has a special uniqueness in the election of management, namely the consequences of pararem or the results of decisions in traditional villages that the adat bendesa or adat prajuru automatically become LPD administrators without looking at the competency of the adat teacher. As we know, adat preachers are chosen in adat meetings based on prarem or deliberation and this is an influence on LPD performance.

\section{Conclusion and Suggestions}

The results of this study prove empirically that LPD organizational performance is influenced by organizational culture but when organizational culture interacts with organizational performance management competencies becomes lower or in other words management competency is not as a moderation of organizational culture relations with LPD organizational performance in Tabanan Regency

This study provides recommendations on the importance of organizational culture and competence in order to improve the performance of LPD organizations. Noting this, the results 
of this study can be utilized by LPD supervisors to pay more attention to the competence of LPD management.

This study has several limitations, namely research has a weak generalization aspect because it only applies in Tabanan Regency. Subsequent research can develop a sample not only in the city of Denpasar but all districts or cities in the province of Bali considering Bali as a world tourist destination supported by strong customs based on the local wisdom economy of the LPD, so the problems in the LPD do not only occur in the district Tabanan only. In addition, local wisdom variables can also be developed which can later be suspected as variables that affect the performance of LPD organizations such as Tri Hita Karana and aspects of the leadership of Asta Brata and Catur Purusa Artha.

\section{References}

[1] Putri, I.G.A.M.D.: Pengaruh Budaya Organisasi Terhadap Kinerja Dalam Perspektif Balanced Scorecard. Jurnal Akuntansi Multiparadigma. Vol. 3(3), pp. 462-470 (2013)

[2] Ozzie, L., and Malelak, M.: Pengaruh Corporate Culture dan Organisational Commitment terhadap Financial Performance Perusahaan Keuangan di Surabaya. Jurnal FINESTA. Vol. 3(1), pp. 79-84 (2015)

[3] Brahmyanti, I.A, Ardiana, I.D.K.R, \& S.: Kompetensi SDM UKM dan Pengaruhnya Terhadap Kinerja UKM di Surabaya. Jurnal Manajemen Dan Kewirausahaan. Vol. 12(1), pp. 42-55 (2010)

[4] Esra, Akta., Cicekb., \& Kiyakc, M.: The Effect Of Organizational Culture on Organizational Efficiency: The moderating Role Of organizational Environment and CEO Values (2011)

[5] Yesil, S., \& Kaya, A.: The Effect Of Organizational Culture On Firm Financial Performance: Evidence From A Developing Country. Procedia - Social And Behavioral Sciences. Vol. 81, pp. 428-437 (2013)

[6] Wardani, R.K., Mukzam, M.D., \& Mayowan, Y.: Pengaruh Budaya Organisasi Terhadap Kinerja Karyawan (Studi Pada Karyawan Pt Karya Indah Buana Surabaya). Jurnal Administrasi Bisnis (JAB). Vol. 31(1), pp. 58-65 (2016)

[7] Koesmono, H.T.: Pengaruh Budaya Organisasi Terhadap Motivasi dan Kepuasan Kerja serta kinerja Karyawan Pada Sub Sektor Industri Pengolahan Kayu Ekspor di Jawa Timur. Disertasi. Universitas Airlangga,Surabaya (2005)

[8] Schein, E.H.: Organizational culture and leadership (2nd ed.). SanFrancisco: Jossey-Bass (1992)

[9] Adriaeni, M. \& P. A. G.: Analysis The Effect of Emotional Intelligence on Performance Through Leadership Style and Organizational Culture as A Moderator. Jurnal Manajemen Dan Teknologi. Vol. 11(3), pp. 250-268 (2012)

[10] Alharbi, M.A., \& M.S.A.: Impact of Organizational Culture on Employee Performance. International Review of Management and Business Research Journal. Vol. 2(1), pp. 168-175 (2013)

[11] Giberson, T.R., Giberson, Christian J., Resick, Marcus W., Dickson Jacqueline K., Mitchelson, Kenneth R., Randall., \& M. A. C.: Leadership and Organizational Culture: Linking CEO Characteristics to Cultural Values. Journal of Business and Psychology. Vol. 24, pp. 123-137 (2009)

[12] Maabuat, E.S.: Pengaruh Kepemimpinan, Orientasi Kerja, Dan Budaya Organisasi Terhadap Kinerja Pegawai (Studi Pada Dispenda Sulut UPTD Tondano. Jurnal Berkala Ilmiah Efisiensi. Vol. 16(1) (2016)

[13] Morgan, G.: Images of organization (2nd ed.). Sage Publication, Oaks (1997)

[14] Schein, E.H.: Culture: the missing concept in organization studies. Administrative Science Quarterly. Vol. 41(2), pp. 229-40 (2009)

[15] Davis, S.M., Kerr, J., \& S.: Managing Corporate Culture. Ballinger Pub, Cambridge (2005)

[16] Callista, N.: Pengaruh Kompetensi SDM Terhadap Kinerja Karyawan Pada PT.Tresnamuda Sejati Cabang Surabaya. Jurnal AGORA. Vol. 4(2) (2016) 
[17] Brahmasari, I.A. \& A.S.: Pengaruh Motivasi Kerja, Kepemimpinan Dan Budaya Organisasi Terhadap Kepuasan Kerja Karyawan Serta Dampaknya Pada Kinerja Perusahaan (Studi Kasus Pada PT. Pei Hai International Wiratama Indonesia). Jurnal Manajemen Dan Kewirausahaan. Vol. 10, pp. 124-135 (2008)

[18] Winarno, A., \& Perdana, Y.: "The Effecs of Competence and Motivation on Employee Performance at PT Pos Indonesia Bandung Cilaki Head Office.” Prancis (2015)

[19] Baba, A.: Pengaruh Kompetensi, Komunikasi Dan Budaya Organisasi Terhadap Kinerjakaryawan PT. Semen Bosowa Maros, Ekuitas. Jurnal Ekonomi Dan Keuangan. Vol. 18(4), pp. 524-540 (2014)

[20] Solimun, Fernandes, A.A.R, \& N.: Metode Statistika Multivariat, Pemodelan Persamaan struktural (SEM) Pendekatan WarpPLS. UB Press (2017) 